\title{
PEMBELAJARAN MENGGUNAKAN PENDEKATAN KONTEKSTUAL BERBANTUAN APLIKASI GEOGEBRA UNTUK MENINGKATKAN KEMAMPUAN PEMECAHAN MASALAH MATEMATIS SISWA
}

\author{
Leni Nurhayati ${ }^{1}$, Ernawati $^{2}$, M. Afrilianto ${ }^{3}$, Luvy Sylviana Zanthy ${ }^{4}$ \\ ${ }^{1,2}$ Program Studi Pendidikan Matematika, IKIP SILIWANGI Bandung \\ Email: ernawati4298@gmail.com
}

\begin{abstract}
Abstrak:
Tujuan dari penelitian ini yaitu untuk menelaah peningkatan kemampuan siswa SMA dalam memecahkan masalah matematis pada materi pokok program linear dengan jenis penelitian yang digunakan adalah penelitian tindakan kelas (PTK). Subjek dalam penelitian ini yaitu siswa kelas XI SMA Leppesa 2 Cililin sebanyak 23 orang pada tahun pelajaran 2019/2020. Instrumen yang digunakan berupa lembar observasi aktivitas guru dan siswa serta tes tulis yaitu pretes dan postest. Prosedur penelitian ini terdiri dari: 1) perencanaan, 2) pelaksanaan tindakan, 3) observasi dan evaluasi, dan 4) refleksi. Hasil penelitian menunjukan bahwa kemampuan siswa dalam memecahkan masalah matematis khususnya pada materi program linear dapat ditingkatkan melalui pendekatan kontekstual yang dikolaborasikan dengan media ICT yaitu aplikasi geogebra.
\end{abstract}

Kata Kunci: Pemecahan Masalah Matematis, Pendekatan Kontekstual, Geogebra

\section{Pendahuluan}

Kemampuan pemecahan masalah merupakan salah satu kemampuan yang harus dikuasai oleh setiap siswa. Seperti yang tercantum dalam peraturan Menteri Pendidikaan Nasional No. 22 Tahun 2006bahwa siswa harus memiliki kemampuan dalam memahami masalah, membuat model matematika,serta menafsirkan solusi dari permasalahan(Armiati \& Febrianti, 2013). Sumarmo (Sumarni \& Umar, 2018) menyatakan bahwa pemecahan masalah adalah salah satu kemampuan yang penting untuk dikuasai sehingga menjadi tujuan umum pengajaran matematika dan merupakan jantungnya matematika.

Selain itu juga, Pomalato (Permatasari \& Margana, 2014) menyatakan bahwa keterampilan yang harus dimiliki seseorang dalam menghadapi kompetisi di masa depan ada dua, yaitu keterampilan memecahkan masalah dan keterampilan berpikir kreatif.Sejalan dengan hal tersebut, Branca (Nanang, 2012) menyatakan bahwa: 1) tujuan umum pembelajaran matematika adalah memiliki kemampuan pemecahan masalah yang merupakan jantungnya matematika, 2) pemecahan masalah dapat meliputi metode, prosedur dan strategi atau cara yang digunakan merupakan proses inti dan utama dalam kurikulum matematika, dan 3) pemecahan masalah sebagai dasar dalam belajar matematika.

Mengingat pentingnya kemampuan pemecahan masalah dalam belajar matematika, maka perlu adanya strategi atau cara yang harus dilakukan oleh guru selaku pembimbing siswa agar kemampuan pemecahan matematis siswa dapat ditingkatkan. Seperti yang dijelaskan Lestari \& Sofyan (2014), salah satu langkah yang bisa dilakukan oleh guru adalah memilih, menerapkan dan memadukan berbagai strategi pembelajaran, metode pembelajaran, dan model pembelajaran yang tepat sesuai dengan kondisi yang ada agar kemampuan pemecahan masalah matematis siswa dapat ditingkatkan sehingga tujuan pembelajaran dapat tercapai secara optimal. Selain itu, pemecahan masalah dapat membantu dalam meningkatkan kemampuan berpikir dalam menyelesaikan masalah matematika (Halim, dkk, 2019). Jatisunda (2016) menyatakan bahwa pendekatan kontekstual adalah satu diantara banyaknya pendekatan pembelajaran yang cocok untuk digunakan agar pembelajaran dapat berjalan dengan baik. 
Adapun tujuan dari pendekatan kontekstual adalah membantu siswa dalam proses pembelajaran karena materi yang dipelajari dikaitkan dengan kehidupan sehari-hari sehingga pembelajaran akan lebih bermakna. Seperti yang dikemukakan Yamin (Jatisunda, 2016) bahwa pembelajaran kontekstual bertujuan untuk membantu peserta didik memahami materi pelajaran yang sedang mereka pelajari dengan menghubungkan pokok materi pelajaran dengan penerapannya dalam kehidupan sehari-hari.

Selain dari pendekatan pembelajaran yang digunakan, penggunaan media pembelajaran juga dapat membantu keefektifan proses pembelajaran. Salah satu media pembelajaran yang bisa digunakan dalam pembelajaran matematika adalah software geogebra. Geogebra solusi yang dapat diberikan untuk oleh guru matematika tersebut adalah dengan memanfaatkan aplikasi/program komputer sebagai media/alat pembelajaran (Zayyadi, dkk, 2017). Syahbana (Sari, Eriani, Audina, \& Setiawan, 2019) menyatakan bahwa geogebra adalah program komputer yang memiliki fungsi sebagai alat untuk memvisualisasikan konsep-konsep matematika yang berguna sebagai media dalam pembelajaran. Penggunaan aplikasi geogebra dapat membantu memvisualisasikan bentuk - bentuk matematika seperti bangun ruang, grafik, kurva dan lain - lain, sehingga dapat memudahkan guru dalam menjelaskan materi dan membantu siswa juga dalam memahami materi yang diajarkan. Geogebra sebagai media pembelajaran matematika untuk meningkatkan kualitas guru matematika (Zayyadi, dkk, 2019).

Berdasarkan uraian diatas, penulis bertujuan untuk melakukan penelitian lebih lanjut berupa penelitian tindakan kelas dengan menerapkan pendekatan kontekstual berbantuan media ICT berupa aplikasi geogebra pada siswa kelas XI SMA dengan materi pokok program linear.

\section{Metode Penelitian}

Penelitian ini adalah penelitian tindakan kelas. Menurut Hopkins (Ni'mah, 2017), penelitian tindakan kelas yaitu salah satu penelitian dengan mengkombinasikan prosedur penelitian dengan tindakan substantif, suatu tindakan yang dilakukan dalam disiplin inkuiri atau suatu usaha seseorang untuk memahami apa yang terjadi, serta terlibat dalam sebuah proses perbaikan dan perubahan. Adapun metode yang digunakan adalah metode deskriptif kualitatif, untuk mendeskripsikan aktivitas antara guru dan siswa ketika pembelajaran dan menelaah bagaimana kemampuan siswa dalam memecahkan masalah matematis setelah melaksanakan pembelajaran menggunakan pendekatan kontekstual. Arikunto (Fatimah \& Khotimah, 2015) menyatakan bahwa penelitian deskriptif adalah penelitian yang dirancang untuk memperoleh informasi tentang status suatu gejala yang terjadi dilapangan pada saat penelitian dilakukan.

Penelitian tindakan kelas yang digunakan menggunakan model Kemmis dan McTaggart (Hendriana \& Afrilianto, 2017) penelitian dilaksanakan selama dua siklus, setiap siklus terdiri dari tahap perencanaan , pelaksanaan tindakan, observasi dan evaluasi, serta tahap refleksi.

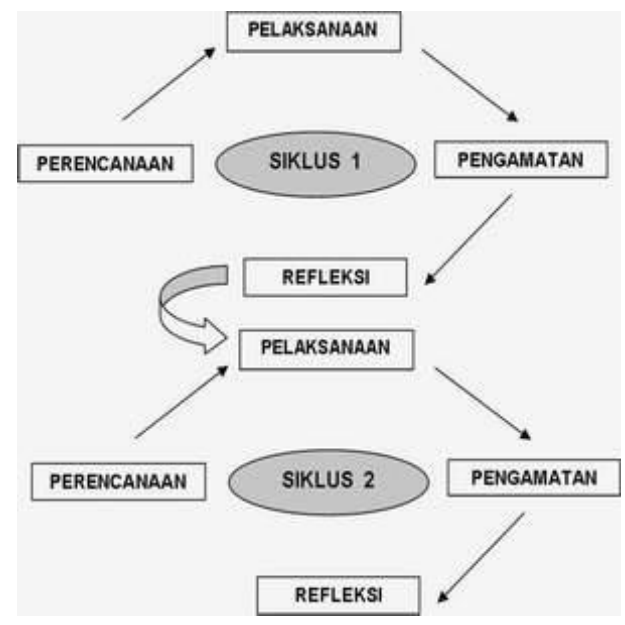

Gambar 1. Skema Penelitian Tindakan

Kelas Berdasarkan Kemmis dan McTaggart 
Penelitian ini dilakukandi kelas XI SMA Leppesa 2 Cililin tahun pelajaran 2019/2020. Subjek penelitian terdiri dari 23.Materi pokok yang diajarkan selama dua siklus penelitian adalah Program Linear. Pengumpulan data dalam penelitian adalah: 1) tes yang dilakukan sebanyak dua kali yaitu sebelum diberi tindakan (pretest) dan sesudah diberi tindakan (postest), 2) observasi, dan 3) dokumentasi untuk mendukung data - data yang didapatkan.

Dalam penelitian ini, Indikator tercapainya peningkatan kemampuan siswa dalam memecahkan masalah matematis yaitu berdasarkan Kriteria Ketuntasan Minimal (KKM). Siswa dikatakan tuntas jika mampu memperoleh nilai minimal 65. Adapun jadwal dari Penelitian Tindakan Kelas (PTK) yang dilakukan adalah:

Tabel 1. Jadwal Penelitian Tindakan Kelas

\begin{tabular}{|c|c|c|}
\hline No & Jenis Kegiatan & $\begin{array}{c}\text { Waktu } \\
\text { Pelaksanaan }\end{array}$ \\
\hline \multirow[t]{2}{*}{1.} & $\begin{array}{l}\text { Tes Awal } \\
\text { (Pretes) }\end{array}$ & 1 Oktober 2019 \\
\hline & \multicolumn{2}{|c|}{ Tindakan Siklus I } \\
\hline 2 & $\begin{array}{l}\text { Pertemuan } 1 \\
\text { Pertemuan } 2\end{array}$ & $\begin{array}{l}8 \text { Oktober } 2019 \\
9 \text { Oktober } 2019\end{array}$ \\
\hline & \multicolumn{2}{|c|}{ Tindakan Siklus II } \\
\hline 3 & $\begin{array}{l}\text { Pertemuan I } \\
\text { Pertemuan II }\end{array}$ & $\begin{array}{l}15 \text { Oktober } 2019 \\
16 \text { Oktober } 2019\end{array}$ \\
\hline 4 & $\begin{array}{l}\text { Tes Akhir } \\
\text { (Postes) }\end{array}$ & $\begin{array}{ll}22 & \text { Oktoberr } \\
2019 & \end{array}$ \\
\hline
\end{tabular}

\section{Hasil dan Pembahasan}

Sebelum dilakukan tindakan siklus I, peneliti memberikan pretes terlebih dahulu untuk mengetahui sejauh mana pemahaman siswa terhadap materi sebelum diberikan tindakan pembelajaran menggunakan pendekatan kontekstual berbantuan software geogebra.

Berikut ini adalah hasil pretes yang diperoleh siswa

\section{Tabel 2. Hasil Pretes Siswa}

\begin{tabular}{cccc}
\hline $\begin{array}{c}\text { No. } \\
\text { Soal }\end{array}$ & $\begin{array}{c}\text { Indikator Pemecahan } \\
\text { Masalah Matematis }\end{array}$ & SMI & $\begin{array}{c}\text { Rata - } \\
\text { rata }\end{array}$ \\
\hline 1 & $\begin{array}{l}\text { Menerapkan strategi } \\
\text { untuk menyelesaikan } \\
\text { masalah sehari - hari }\end{array}$ & 30 & 8,80 \\
\hline
\end{tabular}

\begin{tabular}{|c|c|c|c|}
\hline 2 & \begin{tabular}{l}
\multicolumn{2}{l}{ Merumuskan } \\
masalah matematik \\
atau menyusun \\
model matematik
\end{tabular} & 30 & 7,98 \\
\hline 3 & $\begin{array}{l}\text { Merencanakan dan } \\
\text { menyelesaikan } \\
\text { masalah } \\
\text { rencana }\end{array}$ & 20 & 2,85 \\
\hline 4 & $\begin{array}{l}\text { Memeriksa } \\
\text { kebenaran } \\
\text { perhitungan }\end{array}$ & 20 & 0 \\
\hline & $\begin{array}{c}\text { Rata - rata } \\
\text { Keseluruhan }\end{array}$ & \multicolumn{2}{|c|}{19,63} \\
\hline
\end{tabular}

Berdasarkan hasil pretes diatas, rata rata nilai yang diperoleh siswa adalah 19,63 dari nilai ideal 100. Hal tersebut menunjukan bahwa kemampuan siswa dalam memecahkan masalah dalam soal tersebut masih tergolong rendah. Adapun indikator yang ketercapaiannya paling rendah yaitu indikator memeriksa kebenaran hasil perhitungan dengan rata rata perolehan yaitu 0 , artinya tidak seorang pun yang mampu menyelesaikan masalah dalam soal tersebut.

Berdasarkan hasil pretes tersebut, maka perlu adanya penelitian lebih lanjut untuk meningkatkan kemampuan siswa dalam memecahkan masalah matematis sehingga dilakukan penelitian tindakan kelas menggunakan pendekatan kontekstual berbantuan software geogebra. Dalam penelitian ini, peneliti bertindak sebagai pengajar dan melibatkan observer untuk mengobservasi aktivitas guru dan siswa selama proses pembelajaran. Pembelajaran siklus I dilakukan sebanyak dua pertemuan yaitu pada tanggal 8 dan 9 Oktober 2019. Materi yang dipelajari yaitu mengenai program linear. Pada saat pembelajaran siklus I, guru menggunakan pendekatan kontekstual yaitu pemberian masalah tanpa menggunakan bantuan software geogebra. Berdasarkan hasil observasi pada siklus I, siswa masih mengalami kesulitan dalam memecahkan masalah yang diberikan. Selain itu juga, guru belum mampu mengkondisikan pembelajaran dikelas dengan baik sehingga pembelajaran dirasa kurang efektif. 
Berdasarkan hasil evaluasi pada siklus I, maka diperlukan tindak lanjut pembelajaran untuk memperbaiki kekurangan - kekurangan pada siklus I, yaitu guru kurang mampu mengkondisikan pembelajaran serta siswa kurang mampu menyelesaikan masalah yang diberikan. Oleh karena itu, dilakukan pembelajaran pada siklus II sebanyak dua pertemuan yaitu pada tanggal 15 dan 16 Oktober 2019. Pendekatan pembelajaran yang digunakan pada siklus II yaitu pendekatan kontekstual dengan bantuan software geogebra. Berdasarkan hasil observasi pada siklus II, pembelajaran lebih efektif, siswa lebih aktif dalam bertanya dan mengemukakan pendapatnya. Selain itu juga, pembelajaran berbantuan software geogebra memudahkan guru dalam menjelaskan materi mengenai daerah penyelesaian dari sistem pertidaksamaan yang diberikan karena software geogebra dapat menampilkan grafik yang membuat pembelajaran menjadi lebih visual.

Setelah dilakukan pembelajaran siklus I dan II, guru memberikan postest kepada siswa, untuk mengukur keberhasilan sebelum dan sesudah pembelajaran menggunakan pendekatan kontekstual berbantuan software geogebra. Berikut disajikan hasil postes siswa dan persentase kenaikannya.

Tabel 3. Hasil Postes Siswa

\begin{tabular}{llcccc}
\hline No & $\begin{array}{l}\text { Indikator kemampuan Pemecahan } \\
\text { Masalah Matematis }\end{array}$ & SMI & Pretes & Postes & $\begin{array}{c}\text { Persentase } \\
\text { Kenaikan }\end{array}$ \\
\hline 1 & $\begin{array}{l}\text { Menerapkan strategi untuk } \\
\text { menyelesaikan masalah sehari - hari }\end{array}$ & 30 & 8,80 & 27,85 & $64 \%$ \\
2 & $\begin{array}{l}\text { Merumuskan masalah matematik } \\
\text { atau menyusun model matematik }\end{array}$ & 30 & 7,98 & 24,13 & $54 \%$ \\
3 & $\begin{array}{l}\text { Merencanakan dan menyelesaikan } \\
\text { masalah sesuai rencana }\end{array}$ & 20 & 2,85 & 13,96 & $56 \%$ \\
$\begin{array}{l}\text { Memeriksa kebenaran } \\
\text { perhitungan hasil }\end{array}$ & 20 & 0 & 12,45 & $62 \%$ \\
\hline Rata - rata keseluruhan & 100 & 19,63 & 75,31 & $56 \%$ \\
\hline
\end{tabular}

Berdasarkan tabel diatas, terjadi kenaikan yang signifikan antara hasil pretes dan hasil postes siswa. Rata - rata nilai postes siswa mengalami kenaikan sebesar $56 \%$ yaitu dari 19,63 naik menjadi 75,31. Sehingga secara keseluruhan siswa 100\% tuntas karena nilai yang diperoleh memenuhi kriteria ketuntasan minimal (KKM) yang ditetapkan yaitu 65. Oleh karen aitu, terjadi peningkatan kemampuan siswa SMA dalam memecahkan masalah matematis pada materi pokok program linear.

\section{Simpulan dan Saran}

Berdasarkan hasil penelitian, dapat disimpulkan bahwa pendekatan kontekstual dengan menggunakan media ICT geogebra dapat meningkatkan kemampuan pemecahan masalah matematis siswa khususnya pada materi program linear. Hal tersebut ditunjukan dengan adanya peningkatan nilai yang signifikan yaitu dari nilai rata - rata 19,63 menjadi 75,31 . Selain itu juga, secara keseluruhan maupun perorangan semua siswa dinyatakan lulus karena nilai yang diperoleh memenuhi criteria ketuntasan minimal (KKM) yaitu lebih dari 65 .

\section{Daftar Pustaka}

Armiati, M., \& Febrianti, H. (2013). Efektivitas Penerapan Pendekatan Kontekstual dalam Meningkatkan Kemampuan Pemecahan Masalah Matematika Siswa Kelas VIII SMPN 9 Padang. Prosiding Semirata FMIPA Universitas Lampung, 583590.

Fatimah, S. N., \& Khotimah, R. P. (2015). Analisis Kesulitan Siswa dalam 
Menyelesaikan Soal Ceriita Sistem Persamaan dan Pertidaksamaan Linier di Kelas X SMK Prawira Marta Kartasura Tahun Ajaran 2014/2015. Prosiding Seminar Nasional Pendidikan Matematika UMS, 49-61.

Halim, D., Nisa, S., \& Zayyadi, M. (2019). Solving Math Methods: Model Pembelajaran Berbasis Masalah dengan Komunikasi Matematis untuk Meningkatkan Kemampuan Berpikir. Jurnal Indiktika, 1(2), 103-111.

Hendriana, H., \& Afrilianto, M. (2017). Langkah Praktis Penelitian Tindakan Kelas Bagi Guru. Bandung: PT. Repika Aditama.

Jatisunda, M. G. (2016). Peningkatan Kemampuan Pemecahan Masalah Matematis Siswa SMP Melalui Pembelajaran dengan Pendekatan Kontekstual. Jurnal Theorems (The Original Research of Mathematics), $1(1), 35-44$.

Lestari, L., \& Sofyan, D. (2014). Perbandingan Kemampuan Pemecahan Masalah Siswa dalam Matematika Antara yang Mendapat Pembelajaran Matematika Realistik (PMR) dengan Pembelajaran Konvensional. Jurnal Pendidikan Matematika: Mosharafa, 3, 95-108.

Nanang. (2012). Meningkatkan Kemampuan Siswa dalam Pemecahan Masalah Matematik Melalui Pendekatan Metakognitif. Jurnal Pendidikan Matematika: Mosharafa, 1, 1-9.
Ni'mah, Z. A. (2017). Urgensi Penelitian Tindakan Kelas bagi Peningkatan Profesionalitas Guru Antara Cita dan Fakta. Realita, 15(2), 1-22.

Permatasari, N. Y., \& Margana, A. (2014). Meningkatkan Kemampuan Siswa dalam Memecahkan Masalah Matematika dengan Model Pembelajaran Treffinger. Jurnal Pendidikan Matematika: "Mosharafa," 3, 31-42.

Sari, P. C., Eriani, N. D., Audina, T., \& Setiawan, W. (2019). Pengaruh Pembelajaran Berbantuan Geogebra Terhadap Peningkatan Kemampuan Pemecahan Masalah Matematik Siswa SMP. Journal On Education, 01(03), 411-416.

Sumarni, T., \& Umar, F. I. . (2018). Tinjauan Pemahaman Konsep dan Pemecahan Masalah pada Materi Progrma Linier Siswa SMK Negeri 1 Painan dengan Penerapan Strategi React. Menara Ilmu, XII(11), 151158.

Zayyadi, M., Supardi, L., \& Misriyana, S. (2017). Pemanfaatan Teknologi Komputer Sebagai Media Pembelajaran Pada Guru Matematika. Jurnal Pengabdian Masyarakat Borneo, 1(2), 25-30.

Zayyadi, M., Lanya, H., \& Irawati, S. (2019). Geogebra dan Maple Sebagai Media Pembelajaran Matematika untuk Meningkatkan Kualitas Guru Matematika. Abdimas Dewantara, 2(1), 53-61 